RESEARCH REPORT

\title{
Employment status, employment conditions, and limiting illness: prospective evidence from the British household panel survey 1991-2001
}

\author{
M Bartley, A Sacker, P Clarke
}

See end of article for authors' affiliations

......................

Correspondence to:

Professor M Bartley,

Department of

Epidemiology and Public

Health, University College

London Medical School,

1-19 Torrington Place,

London WCIE 6BT, UK;

mel@public-health.ucl.

ac.uk

Accepted for publication

9 September 2003
J Epidemiol Community Health 2004;58:501-506. doi: 10.1136/jech.2003.009878

Objectives: To assess the relation of the incidence of, and recovery from, limiting illness to employment status, occupational social class, and income over time in an initially healthy sample of working age men and women.

Methods: Cox proportional hazards models.

Results: There were large differences in the risk of limiting illness according to occupational social class, with men and women in the least favourable employment conditions nearly four times more likely to become ill than those in the most favourable. Unemployment and economic inactivity also had a powerful effect on illness incidence. Limiting illness was not a permanent state for most participants in the study. Employment status was also related to recovery.

Conclusions: Having secure employment in favourable working conditions greatly reduces the risk of healthy people developing limiting illness. Secure employment increases the likelihood of recovery. These findings have considerable implications for both health inequality and economic policies.
L imitation of the ability to carry out work because of illness is a growing problem both for business and industry and - for health services. Among adults in Great Britain, the prevalence of limiting long term illness increased from $21 \%$ in 1972 to $35 \%$ in the year $2000 .^{1}$

Research on health inequality and the social determinants of health has shown the importance of unemployment, ${ }^{2-5}$ job insecurity, ${ }^{6-9}$ and employment conditions ${ }^{10-14}$ in the aetiology of chronic disease. However, prospective studies of limiting illness in initially healthy people, and including both men and women, are still somewhat unusual.

In this paper we examine prospectively the relation of employment status and occupational social class to limiting long term illness over an eight year period in a representative sample of men and women who were in excellent or good health at the beginning of the period. Social class is measured according to the National Statistics Socio-economic Classification (NS-SEC), which groups occupations together on the basis of employment conditions such as autonomy, job security, and career prospects. Measures of income, education, and the person's assessment of their employment conditions are included to investigate possible reasons for any observed relations.

\section{METHOD}

\section{Study population}

The British household panel study (BHPS) is a longitudinal survey of private households containing about 5500 households and 10000 men and women. The initial sample was a two stage stratified cluster design, using postcode sectors as the first stage units and individual addresses as the second stage. The first wave of fieldwork took place between September and December 1991. Households have been revisited each year. All eligible household members aged 16 and over are interviewed in the selected households at each wave. This study is based on data from working aged men and women in the years 1991-2001 who were members of the initial 1991 households. Respondents were selected who reported their health as excellent or good with no limiting illness in 1991 and followed up until 2001 or until they dropped out of the survey. There are 2690 of 3598 (75\%) such men aged 21 to 64 years and 2610 of 3629 (72\%) women aged 21 to 59 years in good health. Missing within wave data for the variables of interest reduced the sample to 2335 men and 2296 women.

\section{Measures}

Limiting illness

The survey member is identified with a limiting illness if they respond affirmatively to the question: "Do you have any of the health problems or disabilities listed on this card? Exclude temporary conditions" and also answered affirmatively to the question: "Does your health limit the type of work or the amount of work you can do?"

\section{Social position}

The seven class version of the NS-SEC based on a person's own current or last held occupation is coded for each year of the survey. The NS-SEC classes are: (1) higher managerial and professional occupations; (2) lower managerial and professional occupations; (3) intermediate occupations; (4) small employers and own account workers; (5) lower supervisory and technical occupations; (6) semi-routine occupations; and (7) routine occupations. ${ }^{15}$

\section{Employment status}

Current labour force status is categorised into (1) employed; (2) unemployed; and (3) inactive. The last category comprises those involved in family care, early retirees, students, long term sick, and those on maternity leave or government training schemes.

\section{Qualifications}

Highest academic qualifications are assessed on a six point scale representing the National Vocational levels as follows:

Abbreviations: BHPS, British household panel survey; NS-SEC, National Statistics Socio-economic classification 
(0) no qualifications; (1) CSE grades 2-5 or GCSE grades DF; (2) CSE grade 1, GCE O level, or GCSE grades A-C; (4) GCE A level; (5) further qualification; (6) higher degree level qualification.

\section{Household equivalent income}

This is the annual household income adjusted for the size and composition of the household using the McClements equivalence scale, which takes account of housing costs. ${ }^{16}$ The household equivalent income is ranked into tertiles.

\section{Marital status}

Respondents are classified as either (1) married or living as a couple or (2) other (widowed, divorced, separated, never married).

\section{Conditions of employment (subjective)}

Survey members were asked about their satisfaction with job security, the actual work itself, and the hours worked. Each item was scored on a likert scale from 1 not satisfied at all to 7 completely satisfied.

\section{Statistical analyses}

All modelling is carried out using Stata version 6.0 for Windows (College Station, TX). Separate Cox proportional hazard models are estimated for men and women. For onset of limiting illness, time intervals for the hazard are measured from the start of each period without limiting illness. The hazard at time $\mathrm{t}$ is defined as the probability of limiting illness given no limiting illness since the start of the interval. For recovery from limiting illness, the interval is measured from the onset of the last spell of limiting illness and the hazard at time $t$ is the probability of no limiting illness given no recovery since the start of the interval. The independent variables are all time lagged by one year so that they predict the onset of, or recovery from limiting illness during the year after their measurement. This ensures that changes in health status are not causally associated with changes in the independent variables (for example, employment status).

The models are estimated for both onset of and recovery from limiting illness in three stages. Stage l estimates the effect of each independent variable on the outcome after controlling for age in five year categories. Stage 2 examines the multivariate influence of marital status, social class, employment status, income, and educational qualifications (the fully adjusted model). Finally in stage 3, for those in employment only, the three items relating to conditions of employment are added to the list of independent variables. Social class, employment status, marital status, qualifications, and household equivalent income are entered into the models as time varying covariates. Age in 1991 is a time invariant variable.

\section{RESULTS}

Men were more likely to have higher academic qualification than women, to be married, and on average had more advantaged social class position, and higher income relative to the household's needs (table 1). More women than men were economically inactive, but fewer were unemployed. As several of these independent variables interact with gender to affect limiting illness, results are presented separately for men and women.

\section{Onset of limiting illness}

From the sample of 4631 in good health in 1991, 885 (19\%) experienced a total of 2090 onset events during the period 1992-2001. Thus despite the questionnaire wording to exclude temporary illnesses, limiting illness is a time varying phenomenon and not necessarily a long term condition. Table 2 shows the wording of the health problems checklist and the frequency with which each problem was endorsed over the 10 year period.

Table 3 gives the univariate age adjusted hazard ratios by marital status, social class, job status, qualifications, and household equivalent income for men and women. The effect of social class was broadly similar for men and women in classes $5-7$ but differed when comparing classes $2-4$ with class 1. There was little difference in the risk of limiting illness between higher and lower professional and managerial men. This contrasts with the twofold increased risk of illness for women in class 2 compared with class 1 . The hazard ratio was 2.67 for men in intermediate occupations

Table 1 Distribution of predictors of onset and recovery from limiting illness in the British household panel survey 1991-2001

\begin{tabular}{|c|c|c|}
\hline & Men & Women \\
\hline Person years & 17456 & 17916 \\
\hline Age (mean years in 1991) & 39.39 & 37.76 \\
\hline \multicolumn{3}{|l|}{ Marital status ( $\%$ person years) } \\
\hline Married & 80.09 & 78.58 \\
\hline Other & 19.91 & 21.42 \\
\hline \multicolumn{3}{|l|}{ Social class (\% person years) } \\
\hline (1) Higher professional/managerial & 16.56 & 5.37 \\
\hline (2) Lower professional/managerial & 24.14 & 27.36 \\
\hline (3) Intermediate occupations & 7.56 & 22.96 \\
\hline (4) Small employers and own account & 15.08 & 6.59 \\
\hline (5) Lower supervisory and technical & 14.61 & 5.72 \\
\hline (6) Semi-routine occupations & 9.85 & 18.21 \\
\hline (7) Routine occupations & 12.19 & 13.78 \\
\hline \multicolumn{3}{|l|}{ Employment status (\% person years) } \\
\hline Employed & 87.01 & 74.55 \\
\hline Unemployed & 5.56 & 2.34 \\
\hline Inactive & 7.43 & 23.11 \\
\hline \multicolumn{3}{|l|}{ Highest qualification (\% person years) } \\
\hline None & 17.31 & 19.09 \\
\hline CSE level 2-5 & 7.74 & 4.66 \\
\hline GCE O levels & 17.97 & 31.36 \\
\hline GCE A levels & 11.95 & 9.65 \\
\hline Further qualification & 29.55 & 23.95 \\
\hline Degree or higher qualification & 15.45 & 11.29 \\
\hline Household equivalent income (mean 1991-2001) & 24520 & 23415 \\
\hline
\end{tabular}


but a lower 1.77 for women. There was a graded risk of illness from classes 4 to 7 ranging from a hazard ratio of 2.5 for men in class 5 to a ratio of 3.76 for those in routine occupations. The gradient was somewhat shallower for women.

There was a small increased risk of limiting illness onset for men and women living without a partner. A lack of qualifications and a lower household income predicted a greater risk of illness for men than for women. Unemployment was associated with over twice the hazard of limiting illness in the following year compared with those in employment. However, those not economically active in the previous year were at even greater risk of illness despite the fact that the sample used here was confined to those in excellent or good health in 1991.

In the fully adjusted model, neither marital status nor qualifications had much effect on the risk of illness one year later. Those with higher income had a lower hazard of experiencing a limiting illness, although the magnitude of the effect was small. The effect of occupational class was attenuated by the other independent variables. Allowing for this, men and women in routine occupations were still over twice as likely as those in higher professional or managerial classes to experience a spell of limiting illness in the following year. Unemployment and economic inactivity remained significant predictors of limiting illness in the following year, especially for men. The risk of experiencing a limiting illness among the unemployed was over twice that of the employed. For those out of the labour market, the risk ratios were even greater. After controlling for age, marital status, social class, income, and education, men who were previously healthy were six times as likely to have an onset of limiting illness if they were inactive than if they were in work.

For those in employment (results not shown) three variables were added that measure satisfaction with employment conditions. Occupational social class still had an effect in both men and women after adjustment for subjective satisfaction with conditions of employment. "Satisfaction with work itself" remained a significant predictor in the multivariate analysis.

\section{Recovery from limiting illness}

There were 1994 recovery events among the 753 BHPS members with a limiting illness and follow up data. Forty per cent (305 of 753) were limited by illness for one year only. A further $21 \%$ experienced two years of limiting illness and $12 \%$ were limited for three years. No person reported a limiting illness for the maximum 10 years. Most reported consecutive years with a limiting illness.

Smaller numbers restrict the power to detect differences between groups in these data. Table 4 shows that for men and women, employment status was a strong predictor of recovery from limiting illness, although the effect was restricted to economic inactivity compared with employment in women. There were also differences in recovery between routine occupations and higher professional and managerial occupations. Having no qualifications conferred a higher risk than the highest level of qualifications, and the bottom third of the income distribution a higher risk than the top third. Marital status had no effect on recovery.

Once the other independent variables were taken into account, unemployment was associated with a lower likelihood of recovery among men but not women. Economically inactive men were 2.70 times and inactive women 1.39 times as likely to remain ill as those of the same sex in employment.

\section{DISCUSSION}

There is widespread concern about the rising prevalence of long term limiting illness, and rising numbers of people unable to work because of illness. ${ }^{17-19}$ Because the increases in limiting illness and work disability have taken place at a time of rising life expectancy, some have suspected that changes in the labour market and in employment conditions underlie these trends to some extent. ${ }^{2021}$ Nevertheless, there have been few studies that take a dynamic view of limiting illness over time, and relate this to different aspects of social and economic conditions.

Following up the experience of limiting illness in an initially healthy group of men and women aged 21 to 59 (women) or 21 to 64 (men) over a 10 year period has shown that men and women with less secure and autonomous employment conditions as indicated by the NS-SEC, who are without employment, and who have lower incomes, are more likely to develop a limiting illness. The model estimates that, adjusted for any differences in their income, marital status, or education, a man or woman in the group with the least favourable conditions (SEC 7) had between 2 and 2.5 times the risk of the onset of a limiting illness in the subsequent year compared with those in the most favourable employment conditions (SEC 1). Both men and women also had over twice the hazard of a spell of limiting illness in the year after unemployment.

In the NS-SEC, occupations are allocated into classes according to the degree of autonomy and control over your

Table 2 Proportion of person years with limiting illness by type of health problem* in the British household panel survey 1991-2001

\begin{tabular}{lll}
\hline Description & Men & Women \\
\hline Problems or disability connected with: arms, legs, hands, feet, back, & 3.4 & 4.1 \\
or neck (including arthritis and rheumatism) & & \\
Difficulty in seeing (other than needing glasses to read normal size print) & 0.4 & 0.4 \\
Difficulty in hearing & 0.7 & 0.4 \\
Skin conditions/allergies & 0.4 & 1.2 \\
Chest/breathing problems, asthma, bronchitis & 0.7 & 1.2 \\
Heart/blood pressure or blood circulation problems & 1.2 & 1.0 \\
Stomach/liver/kidneys or digestive problems & 0.7 & 0.7 \\
Diabetes & 0.2 & 0.2 \\
Anxiety, depression, or bad nerves & 0.7 & 1.2 \\
Alcohol or drug related problems & 0.1 & 0.0 \\
Epilepsy & 0.1 & 0.1 \\
Migraine or frequent headaches & 0.5 & 1.3 \\
Other health problems & 0.5 & 0.9 \\
Any health problem & 5.4 & 6.0 \\
Person years & 17456 & 17916 \\
\hline
\end{tabular}

*More than one type of health problem may be reported each year. 
Table 3 Hazard ratios (95\% Cl) for onset of limiting illness in the British household panel survey 1991-2001

\begin{tabular}{|c|c|c|c|c|c|c|}
\hline & \multicolumn{3}{|l|}{ Men $(n=2335)$} & \multicolumn{3}{|c|}{ Women $(n=2296$ ) } \\
\hline & $\begin{array}{l}\text { Onsets/person } \\
\text { years }\end{array}$ & Age adjusted & Fully adjusted & $\begin{array}{l}\text { Onsets/person } \\
\text { years }\end{array}$ & Age adjusted & Fully adjusted \\
\hline \multicolumn{7}{|l|}{ Marital status } \\
\hline Married or cohabiting & $791 / 14607$ & 1.00 & 1.00 & $849 / 14609$ & 1.00 & 1.00 \\
\hline \multicolumn{6}{|c|}{ 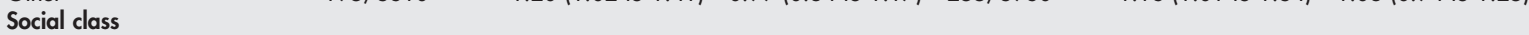 } & $1.08(0.94$ to 1.25$)$ \\
\hline $\begin{array}{l}\text { (1) Higher professional/ } \\
\text { managerial }\end{array}$ & $75 / 3020$ & 1.00 & 1.00 & $22 / 974$ & 1.00 & 1.00 \\
\hline $\begin{array}{l}\text { (2) Lower professional/ } \\
\text { managerial }\end{array}$ & $156 / 4409$ & 1.34 (1.02 to 1.77$)$ & 1.09 (0.83 to 1.45$)$ & $274 / 5093$ & $2.21(1.43$ to 3.41$)$ & 2.14 (1.38 to 3.32$)$ \\
\hline (3) Intermediate occupations & $93 / 1395$ & 2.67 (1.97 to 3.62$)$ & $1.83(1.33$ to 2.51$)$ & $180 / 4289$ & $1.77(1.14$ to 2.76$)$ & $1.67(1.06$ to 2.66$)$ \\
\hline $\begin{array}{l}\text { (4) Small employers and own } \\
\text { account }\end{array}$ & $151 / 2727$ & $1.98(1.50$ to 2.61$)$ & 1.47 (1.09 to 1.98$)$ & $86 / 1188$ & 2.86 (1.79 to 4.57$)$ & 2.42 (1.49 to 3.94$)$ \\
\hline $\begin{array}{l}\text { (5) Lower supervisory and } \\
\text { technical }\end{array}$ & $163 / 2669$ & 2.46 (1.87 to 3.24$)$ & 1.75 (1.30 to 2.35$)$ & $75 / 1080$ & 2.84 (1.76 to 4.57$)$ & 2.37 (1.45 to 3.89 ) \\
\hline (6) Semi-routine occupations & $133 / 1753$ & 2.86 (2.15 to 3.79$)$ & 1.73 (1.26 to 2.37$)$ & $251 / 3370$ & 3.00 (1.94 to 4.65$)$ & 2.54 (1.61 to 4.02 ) \\
\hline $\begin{array}{l}\text { (7) Routine occupations } \\
\text { Employment status }\end{array}$ & $215 / 2244$ & 3.76 (2.89 to 4.90$)$ & 2.27 (1.69 to 3.04$)$ & $216 / 2575$ & 3.45 ( 2.22 to 5.35$)$ & $2.59(1.62$ to 4.13$)$ \\
\hline Employed & $557 / 16008$ & 1.00 & 1.00 & $594 / 14071$ & 1.00 & 1.00 \\
\hline Unemployed & $108 / 986$ & 3.32 (2.69 to 4.08 ) & 2.41 (1.92 to 3.01$)$ & $43 / 443$ & 2.29 (1.68 to 3.12$)$ & $2.06(1.50$ to 2.81$)$ \\
\hline Inactive & $321 / 1223$ & $6.88(5.90$ to 8.03$)$ & $5.83(4.96$ to 6.85$)$ & $467 / 4055$ & $2.82(2.50$ to 3.19$)$ & 2.51 (2.20 to 2.86$)$ \\
\hline \multicolumn{7}{|l|}{ Highest qualification } \\
\hline NVQ level 5 or more & $81 / 2803$ & 1.00 & 1.00 & $109 / 2104$ & 1.00 & 1.00 \\
\hline NVQ level 4 & $251 / 5293$ & 1.49 (1.16 to 1.91$)$ & 1.21 (0.93 to 1.57$)$ & $250 / 4389$ & 1.05 (0.84 to 1.32$)$ & $0.88(0.70$ to 1.11$)$ \\
\hline NVQ level 3 & $87 / 2225$ & 1.37 (1.01 to 1.85$)$ & $0.93(0.68$ to 1.28$)$ & $106 / 1828$ & $1.17(0.90$ to 1.54$)$ & $0.94(0.71$ to 1.25$)$ \\
\hline NVQ level 2 & $212 / 3358$ & 2.18 (1.69 to 2.82$)$ & $1.42(1.07$ to 1.87$)$ & $298 / 5920$ & $0.94(0.76$ to 1.18$)$ & $0.73(0.57$ to 0.94$)$ \\
\hline NVQ level 1 & $95 / 1417$ & $2.29(1.70$ to 3.09$)$ & $1.48(1.07$ to 2.04$)$ & $53 / 897$ & $1.28(0.92$ to 1.77$)$ & $0.81(0.57$ to 1.15$)$ \\
\hline None & $260 / 3121$ & $2.40(1.86$ to 3.10$)$ & $1.24(0.93$ to 1.65$)$ & $293 / 3431$ & $1.39(1.11$ to 1.74$)$ & 0.80 (0.61 to 1.04$)$ \\
\hline \multicolumn{7}{|c|}{ Household equivalent income } \\
\hline Highest tertile & $213 / 6440$ & 1.00 & 1.00 & $270 / 5905$ & 1.00 & 1.00 \\
\hline Middle tertile & $295 / 6184$ & 1.51 (1.26 to 1.80$)$ & 1.11 (0.92 to 1.33$)$ & $302 / 6008$ & $1.13(0.96$ to 1.33$)$ & $1.02(0.86$ to 1.20$)$ \\
\hline Lowest tertile & $478 / 5593$ & $2.92(2.47$ to 3.44$)$ & $1.40(1.16$ to 1.69$)$ & $532 / 6576$ & $1.99(1.71$ to 2.31$)$ & 1.34 (1.13 to 1.59$)$ \\
\hline
\end{tabular}

Table 4 Hazard ratios (95\% Cl) for recovery from limiting illness in the British household panel survey 1991-2001

\begin{tabular}{|c|c|c|c|c|c|c|}
\hline & \multicolumn{3}{|l|}{ Men $(n=351)$} & \multicolumn{3}{|c|}{ Women ( $n=402)$} \\
\hline & $\begin{array}{l}\text { Recoveries/ } \\
\text { person years }\end{array}$ & Age adjusted & Fully adjusted & $\begin{array}{l}\text { Recoveries/ } \\
\text { person years }\end{array}$ & Age adjusted & Fully adjusted \\
\hline \multicolumn{7}{|l|}{ Marital status } \\
\hline Married or cohabiting & $691 / 1381$ & 1.00 & 1.00 & $891 / 1631$ & 1.00 & 1.00 \\
\hline Other & $195 / 374$ & $0.97(0.82$ to 1.15$)$ & $1.04(0.87$ to 1.24$)$ & $217 / 432$ & 0.89 (0.76 to 1.03$)$ & 0.89 (0.76 to 1.04$)$ \\
\hline \multicolumn{7}{|l|}{ Social class } \\
\hline $\begin{array}{l}\text { (1) Higher professional/ } \\
\text { managerial }\end{array}$ & $107 / 177$ & 1.00 & 1.00 & $46 / 62$ & 1.00 & 1.00 \\
\hline $\begin{array}{l}\text { (2) Lower professional/ } \\
\text { managerial }\end{array}$ & $192 / 323$ & $0.91(0.72$ to 1.16$)$ & $1.05(0.82$ to 1.34$)$ & $298 / 545$ & 0.75 (0.55 to 1.03$)$ & $0.83(0.60$ to 1.13$)$ \\
\hline $\begin{array}{l}\text { (3) Intermediate } \\
\text { occupations }\end{array}$ & $76 / 160$ & $0.76(0.56$ to 1.02$)$ & $1.03(0.76$ to 1.40$)$ & $205 / 342$ & 0.80 (0.58 to 1.10$)$ & 0.89 (0.64 to 1.25$)$ \\
\hline $\begin{array}{l}\text { (4) Small employers and } \\
\text { own account }\end{array}$ & $149 / 275$ & $0.86(0.67$ to 1.10$)$ & $1.13(0.86$ to 1.49$)$ & $75 / 153$ & 0.68 (0.47 to 0.98$)$ & 0.79 (0.54 to 1.16$)$ \\
\hline $\begin{array}{l}\text { (5) Lower supervisory and } \\
\text { technical }\end{array}$ & $113 / 245$ & $0.80(0.61$ to 1.04$)$ & $0.99(0.75$ to 1.30$)$ & $68 / 128$ & $0.72(0.49$ to 1.04$)$ & 0.89 (0.60 to 1.32$)$ \\
\hline $\begin{array}{l}\text { (6) Semi-routine } \\
\text { occupations }\end{array}$ & $126 / 251$ & $0.81(0.63$ to 1.06$)$ & $1.15(0.87$ to 1.53$)$ & $233 / 455$ & $0.71(0.52$ to 0.98$)$ & $0.88(0.63$ to 1.24$)$ \\
\hline \multicolumn{6}{|l|}{ Employment status } & $0.89(0.62$ to 1.26$)$ \\
\hline Employed & $734 / 1158$ & 1.00 & 1.00 & $751 / 1230$ & 1.00 & 1.00 \\
\hline Unemployed & $45 / 119$ & $0.58(0.43$ to 0.78$)$ & $0.62(0.46$ to 0.85$)$ & $37 / 71$ & 0.81 (0.58 to 1.12 ) & 0.89 (0.63 to 1.25$)$ \\
\hline $\begin{array}{l}\text { Inactive } \\
\text { Highest qualification }\end{array}$ & $107 / 478$ & $0.35(0.28$ to 0.44$)$ & $0.37(0.29$ to 0.46$)$ & $320 / 762$ & 0.69 (0.60 to 0.78$)$ & 0.72 (0.63 to 0.83 ) \\
\hline NVQ level 5 or more & $131 / 206$ & 1.00 & 1.00 & $157 / 258$ & 1.00 & 1.00 \\
\hline NVQ level 4 & $322 / 556$ & $0.93(0.76$ to 1.15$)$ & $0.99(0.80$ to 1.23$)$ & $330 / 573$ & 0.93 (0.77 to 1.13 ) & $0.93(0.76$ to 1.15$)$ \\
\hline NVQ level 3 & $67 / 142$ & $0.73(0.55$ to 0.99$)$ & 0.91 (0.67 to 1.24$)$ & $107 / 195$ & $0.89(0.69$ to 1.14$)$ & $0.94(0.72$ to 1.22$)$ \\
\hline NVQ level 2 & $131 / 311$ & $0.66(0.51$ to 0.84$)$ & $0.75(0.58$ to 0.99$)$ & $287 / 521$ & 0.89 (0.73 to 1.08 ) & $0.93(0.74$ to 1.16$)$ \\
\hline NVQ level 1 & $84 / 162$ & 0.80 (0.60 to 1.05$)$ & $0.88(0.65$ to 1.20$)$ & $38 / 85$ & $0.71(0.50$ to 1.02$)$ & 0.80 (0.54 to 1.17$)$ \\
\hline None & $151 / 387$ & $0.66(0.52$ to 0.84$)$ & $0.79(0.59$ to 1.03$)$ & $189 / 431$ & $0.73(0.59$ to 0.91$)$ & 0.82 (0.63 to 1.06$)$ \\
\hline \multicolumn{7}{|l|}{$\begin{array}{l}\text { Household equivalent } \\
\text { income }\end{array}$} \\
\hline Highest tertile & $296 / 498$ & 1.00 & 1.00 & $369 / 600$ & 1.00 & 1.00 \\
\hline Middle tertile & $283 / 523$ & $0.90(0.76$ to 1.06$)$ & $1.02(0.86$ to 1.20$)$ & $327 / 621$ & 0.88 (0.76 to 1.02$)$ & 0.93 (0.80 to 1.09 ) \\
\hline Lowest tertile & $307 / 734$ & $0.69(0.59$ to 0.81$)$ & $0.98(0.81$ to 1.18$)$ & $412 / 842$ & $0.77(0.67$ to 0.89$)$ & 0.90 (0.77 to 1.06 ) \\
\hline
\end{tabular}




\section{Key points}

- Secure employment in favourable working conditions are associated with a greatly reduced the risk of healthy people developing limiting illness.

- Lower income is associated with a higher risk of limiting illness, independently of education, social class, education, and employment status.

- Secure employment increases the likelihood of recovery.

- Deterioration in job security may be an important reason behind the increasing prevalence of limiting illness in the community.

own and other people's work, job security, and the presence or absence of career opportunities. It therefore acts as an objective indicator of some aspects of work conditions that have been shown to be of aetiological significance in previous research. ${ }^{80-14}$ The relation of social class to limiting illness may plausibly be attributed in part to these aspects of working conditions.

Limiting illness seems to be a more temporary phenomenon than is normally assumed, for example, in the literature on healthy life expectancy. ${ }^{22-24}$ Recovery was more common than might have been expected, but was also affected by labour market position. Unemployed men were almost $40 \%$, and inactive women over $25 \%$ less likely to recover once an illness had occurred.

The greater likelihood of the onset of limiting illness in those with less favourable employment and labour market situations could be a result of two processes. Healthy men and women with less secure and favourable employment conditions might have developed illness of greater severity than those in better circumstances, or the conditions that did develop might have had more serious consequences for physical and social functioning. In the absence of longitudinal studies carrying out full medical screening every year on a comparable population, this question cannot be answered as yet. As in all longitudinal studies, the BHPS is affected by attrition over the years. Because drop out is known to be more likely among the most and least advantaged in social and economic terms, estimates of health differences between these groups tend to be conservative.

From the point of view of social and economic policies the most relevant information concerns the effect of illness on working capacity. It has long been suspected that the economic gain from increasing pressure on employees, and

\section{Policy implications}

- Increasing "flexibility" in the workforce is often presented as an economic benefit. However, the high levels of job insecurity and low levels of autonomy at work in the UK have not resulted in particularly high economic productivity.

- This paper suggests that less autonomous, more highly supervised work, and lower job security are associated with an increased risk of illness severe enough to limit people's capacity to work.

- There may be hidden costs to labour market "flexibility", not only in terms of the costs of health service provision, but also in terms of economic productivity. from greater "flexibility" of the workforce leaves out of account the costs incurred by excluding larger numbers of people from the workforce, and by possible health effects of increases in job insecurity. ${ }^{25-27}$ The implication of the analysis is that secure and favourable working conditions could considerably reduce the incidence and prevalence of limiting illness in men and women.

Because we have focused on limitation of the capacity for work, the study may also have implications for the wider economy. It is often stated that a more flexible labour market, with lower levels of job security and greater power for managers to direct the work of employees, is more economically productive. However, productivity levels in Great Britain are lower than in many other nations with less labour market flexibility. ${ }^{28}$ This study may indicate that some effort needs to be made to take account of the costs of the limitations to working capacity associated with poor employment conditions and work insecurity. A recent example of such a policy initiative in Great Britain is the introduction by the Health and Safety Executive of a code of practice to improve employment relationships and conditions. ${ }^{29}$ Fortunately, as our analysis shows, measures to improve the conditions of the workforce in these respects are also likely to contribute towards the policy goal of decreasing health inequality.

\section{Authors' affiliations}

M Bartley, A Sacker, P Clarke, Department of Epidemiology and Public Health, University College London Medical School, London, UK

Funding: the work for this paper was funded by MRC Health of the Public grant no 9900586. Mel Bartley's work on the paper was also supported by ESRC Fellowship Grant R000271112

Conflicts of interest: none declared.

\section{REFERENCES}

1 Office for National Statistics. General household survey. London: The Stationery Office, 2001

2 Morris JK, Cook DG, Shaper AG. Loss of employment and mortality. BMJ 1994;308:1135-9.

3 Bethune A. Economic activity and mortality of the 1981 census cohort in the OPCS longitudinal study. Popul Trends 1996;83:37-42.

4 Korpi W. Accumulating disadvantage: longitudinal analyses of unemployment and physical health in representative samples of the Swedish population. European Sociological Review 2001;17:255-74.

5 Bartley M, Plewis I. Accumulated labour market disadvantage and limiting long-term illness: data from the 1971-1991 Office for National Statistics' longitudinal study. Int J Epidemiol 2002;31:336-41.

6 Schnall PL, Landsbergis PA, Pieper CF, et al. The impact of anticipation of job loss on psychological distress and worksite blood-pressure. Am J Ind Med 1992;21:417-32.

7 Ferrie JE, Shipley MJ, Marmot MG, et al. The health effects of major organisational change and job insecurity. Soc Sci Med 1998;46:243-54.

8 Kivimaki M, Vahtera J, Ferrie JE, et al. Organisational downsizing and musculoskeletal problems in employees: a prospective study. Occup Environ Med 2001;58:811-17.

9 Ferrie JE, Shipley MJ, Marmot MG, et al. Job insecurity in white collar workers: towards an explanation of associations with health. J Occup Health Psychol $2001 ; 6: 26-42$.

10 Johnson JV, Stewart W, Hall EM, et al. Long-term psychosocial workenvironment and cardiovascular mortality among Swedish men. Am J Public Health 1996;86:324-31.

11 Stansfeld SA, Bosma H, Hemingway $\mathrm{H}$, et al. Psychosocial work characteristics and social support as predictors of SF-36 health functioning: the Whitehall II study. Psychosom Med 1998;60:247-55.

12 Hemingway $\mathbf{H}$, Nicholson A, Stafford $M$, et al. The impact of socio-economic status on health functioning as assessed by the SF-36 questionnaire: the Whitehall II study. Am J Public Health 1997;87:1484-90.

13 Kuper H, Singh-Manoux A, Siegrist J, et al. When reciprocity fails: effortreward imbalance in relation to coronary heart disease and health functioning in the Whitehall II study. Occup Environ Med 2002;59:777-84.

14 Kivimaki M, Leino-Arjas P, Luukkonen R, et al. Work stress and risk of cardiovascular mortality: prospective cohort study of industrial employees. BMJ 2002;325:857-62.

15 Office of National Statistics. National statistics socioeconomic classification. (http://www.statistics.gov.uk/methods_quality/ns_sec/).

16 Department of Social Security. Households below average income 19791996. London: Corporate Document Services, 1998. 
17 Dickens R, Gregg P, Wadsworth J. New Labour and the labour market. Oxford Review of Economic Policy 2000;16:95-113.

18 OECD. Transforming disability into ability. Paris: OECD, 2003

19 Beatty C, Fothergill S. The detached male workforce. In: Alcock P, Beatty C Fothergill S, et al, eds. Work to welfare. Cambridge: Cambridge University Press, 2003:79-110.

20 Guberan E, Usel M. Permanent work incapacity, mortality and survival without work incapacity among occupations and social classes: a cohort study of ageing men in Geneva. Int J Epidemiol 1998;27:1026-32.

21 Schmitt J, Wadsworth J. Unemployment, inequality and inefficiency. In: Glynn A, Miliband D, eds. Paying for inequality. London: IPPR, 1994:100-13

22 Robine JM, Ritchie K. Healthy life expectancy: evaluation of global indicator of change in population health. BMJ 1991;302:457-60.

23 Robine JM, Michel JP, Branch LG. Measurement and utilization of healthy life expectancy: conceptual issues. Bull World Health Organ 1992;70:791-800.
24 Kelly S, Baker A, Gupta S. Healthy life expectancy in Great Britain 1981-96 and its use as an indicator in UK Government strategies. Health Statistics Quarterly 2000;7:32-7

25 Sen A. Inequality, unemployment and contemporary Europe. International Labour Review 1997;136:155-72.

26 Domenighetti G, D'Avanzo B, Bisig B. Health effects of job insecurity among employees in the Swiss general population. Int J Health Serv 2000;30:477-90

27 Lavis JN, Farrant MS, Stoddart GL. Barriers to employment-related healthy public policy in Canada. Health Promotion International 2001;16:9-20.

28 UK Department of Trade and Industry. International comparisons of productivity (headline data). London: DTI, 2002. http:// www.statistics.gov.uk/downloads/theme economy/ International Comparisons Productivit y Headline tables_Sep02xls (accessed 30 Jun 2003)

29 Pyke N. Pilot scheme to fight stress at work. The Guardian 2003;16 Jun.

\section{APHORISM OF THE MONTH}

\section{"It is easier to change your own behaviour than to change somebody else's"}

A not infrequent criticism of public health is that it is bent on telling other people what to do. The "nanny state" accusation is part of this syndrome, but that will wait another contribution. The main point is that the health and healthcare sectors need to set an example in putting their own houses in order with regard to policies and practices relating to a wide range of public health issues, occupational health policies included. Whether we are talking about alcohol, drugs, tobacco, domestic violence and other family problems, and poverty in some measure among lower grades of staff, or whether we are talking about the Green agenda and sustainable hospitals and healthcare premises, it is difficult to see how we can expect to have credibility in the wider society unless we put our own house in order first, and it should be easier to change our own behaviour than to change somebody else's. 